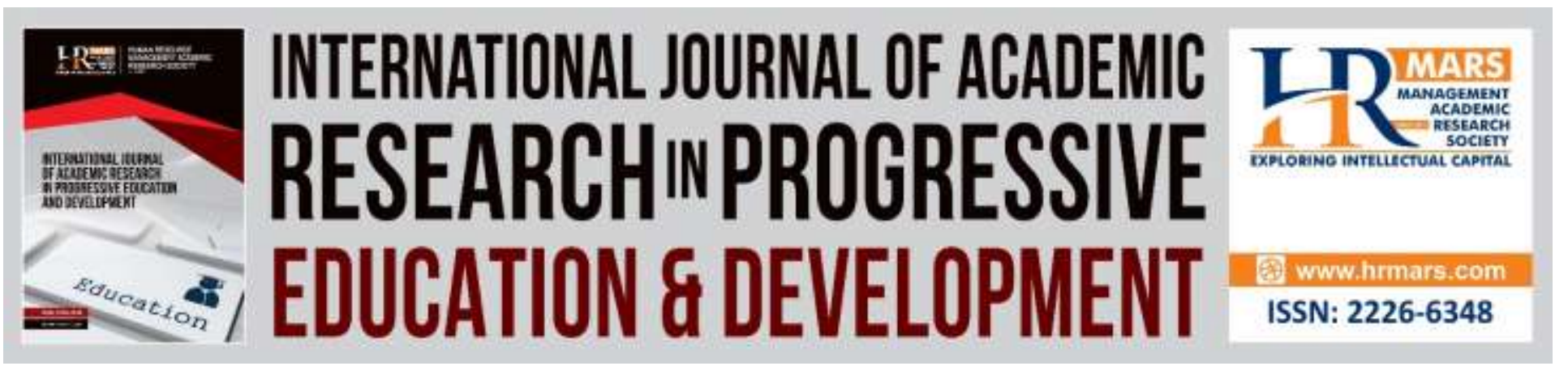

\title{
The Evaluation Scale of Reading Disabilities in The Primary Schools in Northern Territory of Jordan from Learning Resources Room
}

Halaa Freihat, Nashaat Baioumy, Roslan Ab-Rahman, Khaled Abu Sheieah

To Link this Article: http://dx.doi.org/10.6007/IJARPED/v8-i2/5697 DOI: $10.6007 /$ IJARPED/v8-i2/5697

Received: 06 Jan 2019, Revised: 26 Feb 2019, Accepted: 18 March 2019

Published Online: 25 March 2019

In-Text Citation: (Freihat, Baioumy, Ab-Rahman, \& Sheieah, 2019)

To Cite this Article: Freihat, H., Baioumy, N., Ab-Rahman, R., \& Sheieah, K. A. (2019). The Evaluation Scale of Reading Disabilities in The Primary Schools in Northern Territory of Jordan from Learning Resources Room. International Journal of Academic Research in Business and Socal Sciences, 8(2), 213-227.

Copyright: (C) 2019 The Author(s)

Published by Human Resource Management Academic Research Society (www.hrmars.com)

This article is published under the Creative Commons Attribution (CC BY 4.0) license. Anyone may reproduce, distribute, translate and create derivative works of this article (for both commercial and non-commercial purposes), subject to full attribution to the original publication and authors. The full terms of this license may be seen at: http://creativecommons.org/licences/by/4.0/legalcode

Vol. 8(2) 2019, Pg. 213 - 227

Full Terms \& Conditions of access and use can be found at http://hrmars.com/index.php/pages/detail/publication-ethics 


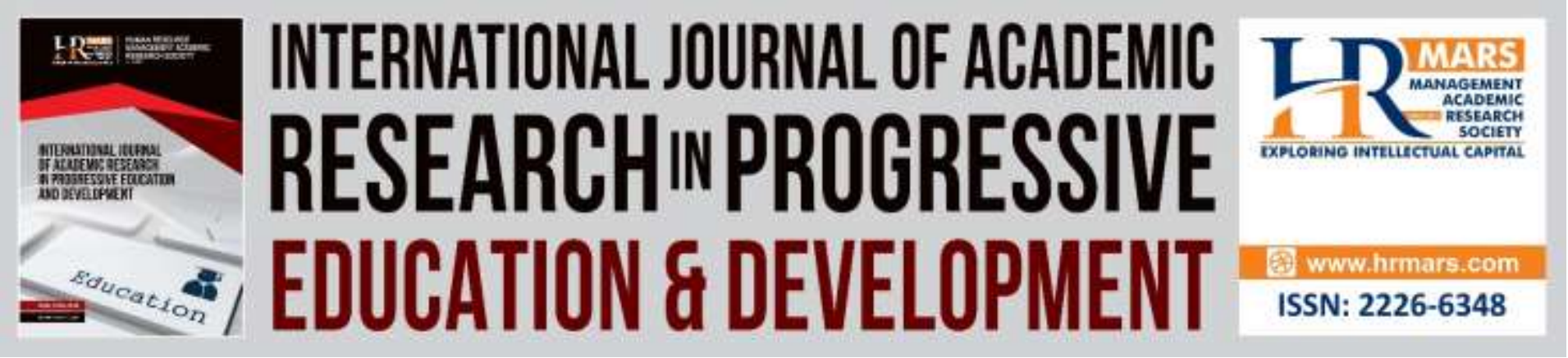

\title{
The Evaluation Scale of Reading Disabilities in The Primary Schools in Northern Territory of Jordan from Learning Resources Room
}

\author{
${ }^{1}$ Halaa Freihat, ${ }^{1}$ Nashaat Baioumy, ${ }^{1}$ Roslan Ab-Rahman, ${ }^{2}$ Khaled \\ Abu Sheieah \\ ${ }^{1}$ Faculty of Islamic Contemporary Studies, University of Sultan Zainal Abidin, 21300, Terengganu, \\ Malaysia \\ ${ }^{2}$ The preparatory Year College, Ha'el University, Saudi Arabia.
}

\begin{abstract}
Many primary school students in Jordan suffer from reading disabilities. Teachers who are concerned with this problem need diagnostic tests and standardized measures to identify these disabilities in order to choose the appropriate intervention methods. Therefore, the present study aimed at exploring the reality that the teachers of the learning resource rooms benefit from the available reading disabilities scales. To achieve the objective of the study, the descriptive analytical method was used and a questionnaire was developed for teachers. The sample consisted of (111) teachers of learning resource rooms in primary schools in the northern region of Jordan. A total of 66 questionnaires were returned. The results indicated that the degree to which teachers benefit from the learning disabilities scales was moderate. The results also revealed that there were no statistically significant differences in subjects' responses due to gender, educational level, and experience. The study recommended the need to hold training courses and workshops for teachers in order to teach them how to use the scales of reading disabilities in particular, and scales of learning in general in order to activate the use of these scales to the maximum possible extent.

Keywords: Reading Disabilities Scales, Teachers of Learning Resource Rooms, The Northern Region of Jordan.

\section{Introduction}

Reading is one of the most important ways to develop human thought. It is one of the first means to acquire knowledge. It is a tool of thinking, communication, and self-expression. It is the source of cognitive and linguistic development. For its importance, the first of the verses that descended on our master Mohammad (peace be upon him) in the Quran was (Read). Reading is the key to learning, knowledge and access to information, and it is one of the most important skills that contribute to making the learner capable of understanding, dialogue and discussion. It is the basis of the progress of the learner in all areas, which requires focusing on this skill, especially in the basic stages of
\end{abstract}


education and the effort to address the difficulties that the learner may encounter in reading at this stage.

Reading disabilities and related symptoms have received a great attention from educational and psychological specialists in recent times, it is one of the most important classes of learning disabilities, and defined as one of learning disabilities that affects the individual and shows his or her inability to read correctly or slow reading due to difficulty in pronunciation of certain letters and words (Aljahni \& Alzraa', 2014).

On the other hand, reading disabilities is one of the most important reasons for the low level of academic achievement of the student, which is at the same time the most common difficulty among students (Dilshad, 2006), to the extent that the reading disabilities reach up to $80 \%$ of the total learning difficulties faced by students (Rainwater-Lawler and Yumori, 2010). Therefore, it is necessary to combine educational efforts to develop appropriate educational programs to treat students in order to facilitate the early detection and diagnosis of reading difficulties and identify and enhance the weaknesses of the students to avoid the outbreak of this problem, which affect a large number of children in primary learning stages (Jabayeb, 2011). Denton (2010), as cited in UNICEF survey (2011) of reading disabilities in primary schools, emphasized the need for children to learn reading skills that differ from speech skills, which develop naturally.

Numerous reasons of reading disabilities had been reported in the literature, the most important of which are social and emotional causes that lead to the difficulty of adapting to colleagues and with the environment and the school climate and loss of self-confidence, and therefore fear of reading, in addition to educational reasons that relate to all elements of the educational process presented by the role of teacher and curriculum methods of education. It is necessary to take into account the individual differences of students and the gradation of their education and create an appropriate educational environment contributes to raise Students self-confidence, and highlights their skills and abilities (Ramdawi \& Kharsi, 2014).

Early detection of reading disabilities at the basic stage is important. It helps to provide early assistance to the students, as well as contribute to address the causes of symptoms, and taking preventive action, thereby reducing the negative impact of these disabilities in the future, due to the fact that the behavioral characteristics of individuals with reading disabilities and related problems can be identified and measured, despite the diversity of the problem from one person to another facilitates the process of making the appropriate decisions.

Teachers have a great role in detecting, diagnosing and determining reading disabilities, especially in the basic stages because it is considered one of the most important stages that establish students' knowledge, skills and behavior. The role of teachers in helping and rehabilitating pupils with reading disabilities, updating their information, and keeping up with research that provides specific tests that measure students' responses in several ways, such as the correct pronunciation of words and examination of character exits, should focus on weaknesses and change the teaching method. until the teacher reaches the appropriate way to which the student responds, in order to solve the 
problem and help the students suffering from it, with the adoption of the daily review of the previous lessons and give him or her more difficult texts gradually to facilitate the process of pronunciation and focus on fixing characters through continuous monitoring, so that he or she can read more easily and better (Alfaqawi, 2015).

Neglecting the early treatment of reading disabilities by teachers makes the problem get worse, thus blocking the way in all fields of knowledge, and thus affect Students' live and future, which requires diagnosis and treatment of the causes of delayed reading and take appropriate action. The diagnosis is a process aimed at determining the ability of the learner to read, which is an essential step to identify aspects of the student's difficulties, from the collection of data on the students concerned and work to analyze and link to access to a successful planning process, including the provision of appropriate educational services.

Therefore, the interest of educational researchers in the development of measures to determine reading disabilities is increasing, and this attention is due to the important role of these measures in making various educational decisions for a particular problem, because these measures help to determine the relationship between responses of individuals to the items in a particular test, Behind those responses, so that they contribute to predicting and defining their behavior in similar situations.

Reading disabilities measures also help teachers to learn about the behavioral and cognitive characteristics of the students and to make the right decisions. Reading disabilities are defined as a set of items developed by specialists that measure or reveal the cognitive characteristics of students with reading disabilities in order to identify the ability of the students to read and pronounce the letters and words correctly. These measures are based on the development of multiple tests through which the diagnosis of the problem and its reasons, and thus classification of students according to the speed of their response to the tests, and the establishment of procedures to deal with them (Albawaliz, 2007).

Measures of reading disabilities are based on the construction of multiple tests to diagnose the difficulties experienced by students in the basic stage. Of course, the aim of these measures is to examine students' skills and ability to speak and read properly, help teachers to learn the steps necessary to communicate with students effectively, and contribute to the development of educational strategies and to provide the appropriate materials to overcome this problem (AbuEdyar, 2012).

In the light of the above literature, one concludes that the use of measure in the field of educational and psychological sciences to diagnose reading disabilities is of great importance and help teachers to identify and diagnose students reading disabilities and the most appropriate way to deal with them, so the current study aims to know the reality of teachers of learning resource rooms in primary schools in the northern region of Jordan benefit from using scales of reading disabilities evaluation for their students, which contributes to providing the necessary assistance to the students. 
INTERNATIONAL JOURNAL OF ACADEMIC RESEARCH IN PROGRESSIVE EDUCATION AND DEVELOPMENT

Vol. 8, No. 2, 2019, E-ISSN: 2226-6348 @ 2019 HRMARS

\section{Problem Statement and Questions}

Measuring reading disabilities gained a great attention from educational experts and psychologists in the recent period as early detection and diagnosis of reading disabilities is one of the most important measures that help the child to overcome this problem, which has negative psychological and social repercussions to his or her life. Therefore, the existence of measures developed by researchers and specialists help identify reading disabilities contribute to identify the first indicators that indicate these disabilities among students and help teachers to diagnose them and take the appropriate decisions. Because teachers have a great influence in discovering and diagnosing students and helping them overcome these disabilities, because they communicate with them directly and continuously, so it is necessary to know the reality of teachers benefit from the reading disabilities measures that help to measure and diagnose these disabilities.

Therefore, the study seeks to answer the following questions:

1. What is the reality that the teachers of the learning resource rooms in the primary schools in the northern region of Jordan benefit from using scales of reading disabilities to evaluate their students?

2. Are there statistically significant differences at the level of significance $(\alpha=0.05)$ in Subjects estimation of the reality that the teachers of the learning resource rooms in the primary schools in the northern region of Jordan benefit from using scales of reading disabilities to evaluate their students due to gender, experience and educational level?

\section{Study Hypotheses}

1. The reality that the teachers of learning resource rooms in the northern region of Jordan benefit from using scales of reading disabilities to evaluate their students is high.

2. There are differences in the reality that the teachers of learning resource rooms in the northern region of Jordan benefit from using scales of reading disabilities to evaluate their students due to gender, experience and educational level.

\section{Study Objectives}

The aim of this study is to identify the reality that the teachers of learning resource rooms in the northern region of Jordan benefit from using scales of reading disabilities to evaluate their students. In addition, the study explores if there are statistically significant differences at the level of $(\alpha=0.05)$ in the estimation of teachers of learning resource rooms in the northern region of Jordan benefit from using scales of reading disabilities to evaluate their students due to gender, experience and educational level.

\section{Study Importance}

The importance of the study lies in the scarcity of studies that examine the reality that the teachers of learning resource rooms in the northern region in Jordan benefit from using scales of reading disabilities to evaluate their students and the extent to which differences varied according to their gender, experience and educational level. It is hoped that this study assists the followings: 
1. The Ministry of Education through studying teaching problems facing the teachers of learning resource rooms, and finding the results that helps to develop some of the competencies of the teachers of the learning resource rooms.

2. The specialists and those involved in learning difficulties as well as the educational supervisors in the field of education to provide them with a research tool that helps to identify how to benefit from the measures of reading difficulties the right way and make the right decisions about disabled students.

3. Researchers in the field of educational and psychological sciences, through the use of the results and recommendations.

\section{Study Limitations}

- Subjective limits: The study seeks to identify the reality that the teachers of the learning resource rooms in the schools of primary schools in the northern region in Jordan benefit from the measures of reading disabilities to evaluate their students.

- Human limits: the population of the study is limited to the teachers of the learning resource rooms.

- Location limits: this study is limited to the primary schools in the northern region of Jordan.

- Time limits: this study is applied during the academic year 2018/2019.

\section{Variables Operational Definitions}

- Reading disabilities is defined as a student inability to read naturally or read in a slow manner. It appears in the form of inability to recognize letters, words and sentences as well as difficulty reading words, inability to connect sentences, and thus inability to read smoothly.

- Measures of reading disabilities is defined as a set of paragraphs that measure or reveal the cognitive characteristics of students with reading disabilities, which are developed by experts and specialists in order to identify the ability of students to read and pronounce letters and words correctly, through which the diagnosis and classification of students according to the speed of their response to the tests, which is reflected on the child's cognitive, psychological and social development.

\section{Previous Studies}

Rddington and Cameron (1999) carried out a study aimed at measuring, diagnosing and treating visual and auditory information among students of reading disabilities. A test was developed to measure the following characteristics: visual perception, auditory perception, visual synergy and visual kinetic synergy. The test was applied to a sample of 17 students reading disabilities, ranged in age from 7-10 years. The results indicated that there are differences in the processing of visual and audio information among students with reading disabilities according to their degree of severity.

Meloy et al., (2002) conducted a study aimed at identifying the effect of reading aloud on students with learning disabilities and on students who do not have reading disabilities. The sample of the study included (260) students, (24\%) of them have reading disabilities and (76\%) of them do not have reading disabilities. They were divided randomly into two groups. Four tests were applied with loud 
INTERNATIONAL JOURNAL OF ACADEMIC RESEARCH IN PROGRESSIVE EDUCATION AND DEVELOPMENT

Vol. 8, No. 2, 2019, E-ISSN: 2226-6348 @ 2019 HRMARS

voices, namely basic skills tests, expression tests, computation tests, problem solving and data analysis.

Gbayeb (2011) conducted a study aimed at identifying literacy disabilities from first grade teachers' perspectives according to gender, scientific qualification, experience and specialization. The study was applied to a random sample of 123 teachers. A questionnaire of 33 items was used. The most important findings of the study are that literacy disabilities are represented by the child's inability to read and write, and that there are statistically significant differences due to the gender in favor of females and qualification for the bachelor's degree. The researcher highlighted the need to pay more attention to educational resources.

Dahlin (2011) conducted a study aimed at examining the relationship of working memory in reading achievement among students with special needs. The study was applied to a sample of 75 Swedish primary school children with special needs. It was first verified whether the working memory of the children in the sample was subject to training and reconstruction during a cognitive training program. The study showed that the training of working memory had a useful effect on developing reading comprehension for children with special needs. The results also showed that the measure of working memory is linked to the reading of the word and children reading comprehension, and that therapeutic interventions to improve working memory can help children to become more proficient in reading comprehension skills.

Al-Mahmood (2013) conducted a study aimed at identifying the level of knowledge of the teachers of the first cycle of primary education in reading disabilities by designing a training program to develop their level and verifying the continuation of the program's effect after several weeks from the end of application. The descriptive approach was used to apply the literacy test to a sample of 305 teachers. The study found that most of the primary stage teachers were moderately knowledgeable about reading disabilities.

Sadiq et al., (2015) conducted a study aimed at developing a measure to diagnose reading disabilities of deaf children and to ascertain the psychometric characteristics of the scale. The primary version of the scale consists of three dimensions. Each dimension measures several skills until the difficulty is diagnosed by the child himself or herself. Reliability and validity of the scale was verified using a sample of 120 deaf children. The study indicated that the psychometric properties of the scale were adequate as the values of Cronbach's alpha and midline were high, which ascertain that scale is usable in the field for which it was designed.

Mansouri and Arum (2015) carried out a study aimed at identifying the types of reading disabilities experienced by students in the second and third grades of primary school, to identify differences between these two levels, as well as gender differences in reading disabilities. A sample of students from the second ( 31 students) and the third (33 students) grades from three primary schools located in Mostaganem province in Algeria, were selected, including 30 males and 34 females. The test of diagnosing reading disabilities (Dr. Salah Amira Ali) was applied to after adaptation to the Algerian environment. The study found the following results: There are statistically significant differences 
between the males and females reading disabilities (knowing and reading words, the difficulty of recognizing the parts of the word and their integration, the difficulty of linking the written code and the operative sound and the difficulty of audio discrimination) in favor of males. There were statistically significant differences between the second and third years of elementary school in reading disabilities in favor of second year students.

Shukla and Agrawal's study (2015) aimed to educate teachers in primary schools on learning disabilities using a sample of 68 teachers from primary schools in an Indian region. After collecting data from teachers by questionnaire, the study found a low level of knowledge of learning disabilities among teachers of the primary stage of learning disabilities of students, because of the lack of training received by teachers in this area.

Al-Farra (2016) conducted a study aimed at detecting and diagnosing reading disabilities, designing an observation card and learning methods according to the opinion of a sample of teachers of grades 1-6 in primary education in public schools and UNRWA schools in Khan Younis, Gaza. Three questionnaires were used in the study. The results of the first questionnaire showed that the domains obtained a medium degree, and that the order of disabilities descending came as follows: disabilities related to the family and the community first, the learner, the nature of the Arabic language and characteristics, school, educational supervision, and teacher as well as methods of assessment and the text book. The study revealed a difference in statistical significance due to the gender and experience in grades (1-3) and (4-6). The second questionnaire is a diagnosing card of reading disabilities in the primary stage in two domains: reading pronunciation domain with a medium degree and reading comprehension skills with a high degree. The third questionnaire suggested several methods for the treatment of reading disabilities for the primary stage grades with a high degree.

It was noted that the previous studies dealt with different topics related to the main concepts in this study. Variables, relations, populations and samples of those studies were varied from one study to another and hence different results. What distinguishes the current study from previous studies is that it is the first study, according to researchers' best knowledge, that shed light on the reality that the teachers of learning resource rooms in the primary education schools in the northern region in Jordan are able to measure the reading disabilities among their students using the descriptive analytical approach by developing a questionnaire to show the relationship between the independent factors of the study (gender, experience and educational level) of teachers of learning resource rooms in the northern region in Jordan. This study is a positive step that may contribute to providing a preliminary perception of the reality of teachers benefit from such scales.

\section{Methodology}

\section{Study Method}

The objective of the study is to identify the reality that the teachers of learning resource rooms in the primary schools in the northern region of Jordan benefit from using scales of reading disabilities to evaluate their students, to achieve this goal, the descriptive analytical method was used. 
INTERNATIONAL JOURNAL OF ACADEMIC RESEARCH IN PROGRESSIVE EDUCATION AND DEVELOPMENT

Vol. 8, No. 2, 2019, E-ISSN: 2226-6348 @ 2019 HRMARS

\section{Study Population and Sample}

The population consists of 222 teachers of learning resource rooms in the north region in Jordan. A sample of $50 \%$ of the study population was selected, i.e., the sample of the study comprised 111 teachers. After the distribution of the, a total of 66 responses were returned with a response rate of $60 \%$.

\section{Study Measurement}

A five-point Likert questionnaire was developed by reference to previous relevant studies. It consisted of 18 items anchored as follows: extremely high (5), high (4), moderate (3), low (2) and extremely low (1). The following scale was used to assess the means of subjects' responses: low (1less than 2.34), moderate (2.34-less than 3.68) and high (3.68-5).

\section{Validity}

The tool was initially presented to a panel of experts consisted of (5) specialized experts in order to determine the suitability and clarity of the items, its linguistic integrity, any proposed amendments, proposed items as they deem necessary, and the deletion of unnecessary items. An agreement criterion of $80 \%$ was used to accept committee for amendment, deletion and addition.

\section{Reliability}

Internal consistency of the questionnaire items using Cronbach's alpha was used to check the reliability of the questionnaire. The coefficient of the questionnaire as a whole was 0.89 , which is good, as it exceeded the value of 0.70 . Hence, the collected data is therefore suitable for measuring variables and is subject to a high degree of reliability.

\section{Study Variables}

1. Independent variables

- Estimations of teachers of learning resource rooms in the primary schools in the northern region of Jordan.

\section{Mediating variables}

- Gender: male and female.

- Years of experience: less than 5 years, 5-10 years and more than 10 years.

- Educational level: Bachelor, Master and Doctorate.

\section{Dependent variables}

- The reality that the teachers of learning resource rooms in the primary schools in the northern region of Jordan benefit from scales of reading disabilities to evaluate their students.

\section{Study Procedures}

The following steps were followed in order to find the results:

- Preparing the theoretical literature of the study by reviewing references.

- Description of the study population, the sample, the study tool and the necessary statistical procedures.

- Preparing the study tool and computing reliability and validity indices. 
Vol. 8, No. 2, 2019, E-ISSN: 2226-6348 @ 2019 HRMARS

- Appling of the study tool on the sample of the teachers of learning resource rooms in the northern region, Jordan. Distribution and collecting the study tool took 3 weeks.

- $\quad$ Data were analyzed using IBM SPSS 24.0.

- Presenting and discussing the results and providing the recommendations.

\section{Data Analysis and Results}

Frequencies and percentages were extracted in order to identify the distribution of the sample by gender, experience and educational level. The results are shown in Table (1).

Table 1. Distribution of sample members by gender, experience and educational level

\begin{tabular}{|l|c|c|c|c|c|c|}
\hline & \multicolumn{2}{|c|}{ Gender } & \multicolumn{2}{c|}{ Experience } & \multicolumn{2}{c|}{ Educational level } \\
\hline & $\mathrm{F}$ & $\%$ & $\mathrm{~F}$ & $\%$ & $\mathrm{~F}$ & $\%$ \\
\hline Male & 25 & 37.9 & & & & \\
\hline Female & 41 & 62.1 & & & & \\
\hline Less than 5 years & & & 18 & 27.3 & & \\
\hline 5-10 years & & & 31 & 47 & & \\
\hline $\begin{array}{l}\text { More than 10 } \\
\text { years }\end{array}$ & & & 17 & 25.8 & & \\
\hline Bachelor & & & & & 60 & 90.9 \\
\hline Master & & & & & 6 & 9.1 \\
\hline Doctorate & & & & & - & - \\
\hline Total & 66 & 100 & 66 & 100 & 66 & 100 \\
\hline
\end{tabular}

It is clear from the table that the percentage of females was $62 \%$ compared to the percentage of males which was 38\%, and the largest proportion of respondents have years of experience from 5 to 10 years, reaching $47 \%$, and that about $27 \%$ of the sample have years of experience less over 5 years, followed by about $26 \%$ who have years of experience more than 10 years.

\section{Hypotheses Testing}

Means and standard deviations of the sample responses were extracted in order to test the first hypothesis, which states that "the reality that the teachers of learning resource rooms in the northern region of Jordan benefit from using scales of reading disabilities to evaluate their students is high". The results are shown in Table 2. 
INTERNATIONAL JOURNAL OF ACADEMIC RESEARCH IN PROGRESSIVE EDUCATION AND DEVELOPMENT

Vol. 8, No. 2, 2019, E-ISSN: 2226-6348 @ 2019 HRMARS

Table 2. Means and standard deviations of sample estimations

\begin{tabular}{|c|c|c|c|c|c|}
\hline No. & Item & Mean & SD & Rank & Degree \\
\hline 18 & $\begin{array}{l}\text { Measures of reading disabilities make it easier for } \\
\text { teachers to identify the strengths and weaknesses of the } \\
\text { students }\end{array}$ & 4.17 & 0.90 & 1 & High \\
\hline 1 & $\begin{array}{l}\text { Measures of reading disabilities make it easier for } \\
\text { teachers to collect data on their students }\end{array}$ & 4.12 & 0.96 & 2 & High \\
\hline 3 & $\begin{array}{l}\text { Measures of reading disabilities provide necessary } \\
\text { information to the teacher about the characteristics, } \\
\text { abilities and readiness of the students }\end{array}$ & 4.05 & 0.90 & 3 & High \\
\hline 10 & $\begin{array}{l}\text { Measures of learning difficulties help to explain why } \\
\text { students are unable to read }\end{array}$ & 3.92 & 0.84 & 4 & High \\
\hline 2 & $\begin{array}{l}\text { Measures of reading disabilities offer certain methods } \\
\text { to create an appropriate planning process that ensures } \\
\text { treatment of students }\end{array}$ & 3.83 & 0.97 & 5 & High \\
\hline 17 & $\begin{array}{l}\text { Measures of reading disabilities help teachers to renew } \\
\text { their knowledge towards their students }\end{array}$ & 3.83 & 0.82 & 5 & High \\
\hline 15 & $\begin{array}{l}\text { Measures of reading disabilities provide standardized } \\
\text { reading tests }\end{array}$ & 3.74 & 0.81 & 7 & High \\
\hline 16 & $\begin{array}{l}\text { Measures of reading disabilities help teachers to } \\
\text { provide appropriate treatment methods for their } \\
\text { students }\end{array}$ & 3.65 & 0.82 & 8 & $\begin{array}{l}\text { Modera } \\
\text { te }\end{array}$ \\
\hline 9 & $\begin{array}{l}\text { Measures of reading disabilities help teachers to analyze } \\
\text { data on their students }\end{array}$ & 3.65 & 0.74 & 8 & $\begin{array}{l}\text { Modera } \\
\text { te }\end{array}$ \\
\hline 6 & $\begin{array}{l}\text { Measures of reading disabilities help teachers to classify } \\
\text { their students into homogeneous groups }\end{array}$ & 3.58 & 0.68 & 10 & $\begin{array}{l}\text { Modera } \\
\text { te }\end{array}$ \\
\hline 7 & $\begin{array}{l}\text { Measures of reading disabilities make it easier for } \\
\text { teachers to prepare appropriate individual educational } \\
\text { plans for students }\end{array}$ & 3.47 & 0.75 & 11 & $\begin{array}{l}\text { Modera } \\
\text { te }\end{array}$ \\
\hline 8 & $\begin{array}{l}\text { Measures of reading disabilities help teachers to judge } \\
\text { the effectiveness of individual educational plans } \\
\text { appropriate for students }\end{array}$ & 3.45 & 0.72 & 12 & $\begin{array}{l}\text { Modera } \\
\text { te }\end{array}$ \\
\hline 5 & $\begin{array}{l}\text { Measures of reading disabilities help teachers to design } \\
\text { appropriate programs for students }\end{array}$ & 3.35 & 0.72 & 13 & $\begin{array}{c}\text { Modera } \\
\text { te }\end{array}$ \\
\hline 14 & $\begin{array}{l}\text { Measures of reading disabilities provide appropriate } \\
\text { tools to identify students with reading disabilities }\end{array}$ & 3.33 & 0.65 & 14 & $\begin{array}{l}\text { Modera } \\
\text { te }\end{array}$ \\
\hline 4 & $\begin{array}{l}\text { Measures of reading disabilities help teachers to make } \\
\text { informed decisions about their students }\end{array}$ & 3.20 & 0.72 & 15 & $\begin{array}{l}\text { Modera } \\
\text { te }\end{array}$ \\
\hline 13 & $\begin{array}{l}\text { Measures of reading disabilities help teachers to } \\
\text { identify and describe the behavior of the students }\end{array}$ & 3.12 & 0.69 & 16 & $\begin{array}{l}\text { Modera } \\
\text { te }\end{array}$ \\
\hline 12 & $\begin{array}{l}\text { Measures of reading disabilities help teachers to detect } \\
\text { developmental problems among students }\end{array}$ & 3.12 & 0.54 & 17 & $\begin{array}{l}\text { Modera } \\
\text { te }\end{array}$ \\
\hline
\end{tabular}


INTERNATIONAL JOURNAL OF ACADEMIC RESEARCH IN PROGRESSIVE EDUCATION AND DEVELOPMENT

Vol. 8, No. 2, 2019, E-ISSN: 2226-6348 @ 2019 HRMARS

\begin{tabular}{|c|l|c|c|c|c|}
\hline 11 & $\begin{array}{l}\text { Measures of reading disabilities help teachers to predict } \\
\text { the situation of the students concerned according to the } \\
\text { information available about them }\end{array}$ & 3.08 & 0.82 & 18 & $\begin{array}{c}\text { Modera } \\
\text { te }\end{array}$ \\
\hline Total & 3.59 & 0.70 & - & $\begin{array}{c}\text { Modera } \\
\text { te }\end{array}$ \\
\hline
\end{tabular}

The results in Table 2 show that the total degree of teachers' benefit from the measures of reading disabilities was moderate $(M=3.59, S D=0.70)$. Consequently, hypothesis 1 was rejected. Items no. 1 , which states that "measures of reading disabilities make it easier for teachers to identify the strengths and weaknesses of the students" ranked first with a high degree ( $M=4.17, S D=0.90)$, while item no. 11, which states that "Measures of reading disabilities help teachers to predict the situation of the students concerned according to the information available about them", ranked last with a moderate degree $(M=3.08, S D=0.82)$.

T-test and ANOVA were conducted to test the second hypothesis, which presumes that "there are differences in the reality that the teachers of learning resource rooms in the northern region of Jordan benefit from using scales of reading disabilities to evaluate their students due to gender, experience and educational level". The results related to differences due to gender are shown in Table 3 and results of differences due to experience and educational level are shown in Table 4.

Table 3. T-test for differences due to gender

\begin{tabular}{|c|c|c|c|c|}
\hline Variable & Mean & SD & t & Sig. \\
\cline { 1 - 3 } Male & 3.67 & 0.70 & \multirow{2}{*}{0.736} & \multirow{2}{*}{0.465} \\
\hline Female & 3.54 & 0.69 & \\
\hline
\end{tabular}

The results in Table 3 show that there are clear differences between the mean of male respondents $(M=3.67, S D=0.70)$ and the mean of female respondents $(M=3.54, S D=0.69)$. However, these differences were no statistically significant $(t=0.736$, Sig. $=0.465)$.

Table 4. ANOVA for differences due to experience

\begin{tabular}{|l|c|c|c|c|c|}
\hline \multicolumn{1}{|c|}{ Variable } & Number & Mean & SD & F & Sig. \\
\hline Less than 5 years & 18 & 3.67 & 0.76 & & \multirow{2}{*}{0.25} \\
\cline { 1 - 4 } 5-10 years & 31 & 3.53 & 0.71 & 0.771 \\
\cline { 1 - 3 } More than 10 & 17 & 3.62 & 0.59 & & \\
\hline
\end{tabular}

The results in Table 4 show that there are clear differences between the mean of respondents who have experience less than 5 years $(M=3.67, S D=0.76)$, the mean of respondents who have experience ranges between 5 and 10 years $(M=3.53, S D=0.71)$ and the mean of respondents with more than 10 years of experience $(M=3.62, S D=0.59)$. However, these differences were no statistically significant $(F=0.250$, Sig. $=0.771)$. 
INTERNATIONAL JOURNAL OF ACADEMIC RESEARCH IN PROGRESSIVE EDUCATION AND

DEVELOPMENT

Vol. 8, No. 2, 2019, E-ISSN: 2226-6348 @ 2019 HRMARS

Table 5. ANOVA for differences due to educational level

\begin{tabular}{|l|c|c|c|c|c|}
\hline \multicolumn{1}{|c|}{ Variable } & Number & Mean & SD & F & Sig. \\
\hline Bachelor & 60 & 3.56 & 0.70 & & \multirow{2}{*}{0.92} \\
\cline { 1 - 3 } Master & 6 & 3.85 & 0.58 & & 0.341 \\
\hline Doctorate & - & - & - & & \\
\hline
\end{tabular}

The results in Table 5 show that there are clear differences between the mean of respondents who hold bachelor degrees $(M=3.56, S D=0.70)$ and the mean of respondents who hold Master degrees $(\mathrm{M}=3.85, \mathrm{SD}=0.58)$. However, these differences were no statistically significant $(\mathrm{F}=0.920, \mathrm{Sig} .=$ $0.341)$. On the basis of the above-mentioned analyses, hypothesis 2 was rejected.

\section{Discussion}

The results of the study showed that the degree of teachers' benefit from measures of reading disabilities was moderate. This may be due to the fact that the existing measures, although their benefit for teachers, have not reached the required level of these measures. Particularly, in domains like the provision of remedial approaches that are suitable for students, the ability to rely on these measures to analyze students data, facilitate the classification of students into appropriate classes, prepare individual educational plans, assess their effectiveness, provide appropriate tools by which students with reading disabilities can be identified and allocated for appropriate programs, take decisions, to detect their developmental problems and to predict the conditions of students according to the information available about them. This result was agreed with the study of AlMahmood (2013) and Al-Farra (2016), which showed a medium degree on the items assigned to detect and diagnose reading disabilities.

On the other hand, the results showed that there were no statistically significant differences in the responses of the sample members on the benefit of the measures of learning disabilities. This result was agreed with the results of some previous studies, including the study of Jabayeb (2011), which showed differences in the teachers' responses on the literacy disabilities according to gender and educational level and the absence of differences due to experience and specialization, as well AlFarra study (2016), which showed differences due to the gender and experience.

\section{Recommendations}

1. Conducting training courses and workshops that show teachers the best way to use learning disabilities measures.

2. Instructing teachers on the significance of learning disabilities measures and how to use these measures to analyze students' data, classifying them according to the severity of the disability, preparing educational plans, and designing appropriate programs to deal with them.

\section{Acknowledgement}

Special thanks to Research Management, Innovation \& Commercialization Centre (RMIC) and University Sultan Zainal Abidin (UniSZA) for funding this research. 
INTERNATIONAL JOURNAL OF ACADEMIC RESEARCH IN PROGRESSIVE EDUCATION AND

DEVELOPMENT

Vol. 8, No. 2, 2019, E-ISSN: 2226-6348 @ 2019 HRMARS

\section{References}

AbuDiar, M. (2012). Measurement and diagnosis of learning disabilities. Child Assessment and Education Center: Kuwait, Ed. 1.

Albawaliz, M. (2007). Building a multidimensional measure of cognitive abilities to identify and diagnose learning disabilities for the age group (8-11 years). Unpublished doctoral dissertation, Amman Arab University for Higher Studies.

Alfaqawi, J. (2009). The Effectiveness of a proposed program in the treatment of spelling difficulties among seventh grade students in Khan Yunis Governorate, Unpublished Master Thesis: Islamic University, Gaza.

Al-Farra, I. (2016). Difficulties in reading, diagnosing, observing and processing methods according to the views of the teachers of the basic stage, Journal of the Islamic University for Economic and Administrative Studies, 25 (2), 310-346.

Aljahni, S. \& Alzraa', N. (2014). Obstacles to the Use of Teachers with Learning Disabilities for Supporting Educational Methods in Teaching Reading, International Specialized Educational Journal, 3 (10).

Alkasaba, H. (2015). Building a measure of social phobia in the students of the University of Jordan according to the modern theory of measurement, unpublished master thesis, Mu'tah University, Jordan.

Dahlin, E. (2011). Effects of working memory training of reading in children with special needs, reading and writing. An Interdisciplinary Journal, 24(4), 479-491.

Dilshad, H. (2006). Prevalence of learning difficulties / disability among primary school children: Effect on emotional problems and academic achievement. A Master Thesis, University of Agricultural Sciences, Dharwad.

Jabayeb, A. (2011). The difficulties of reading and writing from the point of view of the primary first grade teachers, Al-Azhar University Journal, Gaza, 13 (1), 1-34.

Khairuldin, W. M. K. F. W. (2018). Fatwa Role in Education and Legal Dispute in Malaysia. International Journal of Academic Research in Progressive Education and Development, 7(4), 295-302.

Khairuldin, W. M. K. F. W., Embong, A. H., Anas, W. N. I. W. N., Mohd, H. \& Ismail, D. (2018). The Application of Technology in the Dissemination of Fatwas: A Study on Religious Institutions in Malaysia, International Journal of Civil Engineering and Technology, 9(7), 2018, pp. 1590- 1596.

Khairuldin, W. M. K. F. W., Embong, A. H., Anas, W. N. I. W. N., Ismail, D., \& Mokhtar, W. K. A. W. (2019). An Augmented Reality (AR) Approach in Educational Integration of Du'a in Islam. Journal of Academic Research in Progressive Education and Development, 8(1), 32-39

Al-Mahmood, A. H. (2013). The effectiveness of a training program in developing the level of knowledge of teachers of the first cycle of basic education for the difficulties of reading and writing, unpublished Master Thesis. University of Damascus, Syria.

Mansouri, M. and IbnArum, W. (2015). Reading difficulties for second and third year students, primary. Journal of Psychological and Educational Studies, 14 January 2015.

Meloy, L., Deville, C. and Frisbie, D. (2002). The effect of a read-aloud accommodation on test scores of students with and without a learning disability in reading. Remedial and Special Education, 23 (4), 248-255.

Rainwater-Lawler \& Yumori (2010). Diagnosing reading disabilities at a graduate school Level. Optometric Education, 36(1), 24-28. 
Ramdawi, A. \& Kharami, F. Z. (2014). Indicators of reading and writing disabilities among second year students from the teachers' perspective. Graduation project for the Bachelor of Science in Educational Technology, University of Moulay Eltaher: Algeria

Reddington, J. and Cameron, K. (1991). Visual and auditory information processing in dyslexia: The possibility of sub-types. International Journal of Disability, Development and Education, 38(2), 171203.

Sadiq, F., Mohammed, A., \& Tantawi, M. (2015). Diagnostic scale of learning disabilities in deaf children. Journal of the Faculty of Education: Ain Shams, 39 (3), 395-427.

Shukla, P. and Agrawal, G. (2015). Awareness of learning disabilities among teachers of primary schools. Online Journal of Multidisciplinary Research (OJMR), 1(1), 33-38.

UNICEF (2011). Survey of learning disabilities in primary schools. 